\title{
POZZOLANIC ACTIVITY OF METAKAOLINS BY THE FRENCH STANDARD OF THE MODIFIED CHAPELLE TEST: A DIRECT METHODOLOGY
}

\author{
Eduardo FERRAZ $^{1 \text { ) *, Slávka ANDREJKOVIČOVÁ }}{ }^{\text {2) }}$, Walid HAJJAJI ${ }^{2)}$, Ana Luísa VELOSA ${ }^{3)}$, \\ António Santos SILVA ${ }^{4)}$ and Fernando ROCHA ${ }^{2)}$ \\ 1) Polytechnic Institute of Tomar, Geobiotec Research Unit. Quinta do Contador, Estrada da Serra, PT - 2300-313 Tomar, Portugal \\ ${ }^{2)}$ Geosciences Department, University of Aveiro, Geobiotec Research Unit. Campus Universitário de Santiago, \\ PT - 3810-193 Aveiro, Portugal \\ 3) Civil Engineering Department, University of Aveiro, Geobiotec Research Unit. Campus Universitário de Santiago, \\ PT - 3810-193 Aveiro, Portugal \\ 4) Materials Department, National Laboratory for Civil Engineering, Avenida do Brasil, 101, PT - 1700-066 Lisboa, Portugal
}

*Corresponding author's e-mail: ejmoferraz@ipt.pt; ejmoferraz@gmail.com

\section{ARTICLE INFO}

Article history:

Received 19 January 2015

Accepted 26 May 2015

Available online 13 July 2015

Keywords:

Particle size

Calcined kaolins

Laboratorial chemical test

Cation exchange capacity

Specific surface area

Particle morphology

\begin{abstract}
This research was focused on the use of the modified Chapelle test as a direct laboratory methodology to access the pozzolanic activity of both experimental and commercial metakaolins. At the same time, this test was used in the evaluation of experimental metakaolins. This chemical test, performed during 16 hours at $90{ }^{\circ} \mathrm{C}$, allows the quantification of portlandite fixed by the metakaolin sample. The calcium hydroxide that was not consumed is quantified by acid titration $(\mathrm{HCl})$, and the test result is expressed in $\mathrm{mg}$ of fixed calcium hydroxide by $\mathrm{g}$ of metakaolin. According to this test, the pozzolanic activity of a metakaolin should not be less than $700 \mathrm{mg} \mathrm{Ca}(\mathrm{OH})_{2} / \mathrm{g}$ metakaolin.

The modified Chapelle pozzolanic activity of six commercial metakaolins was evaluated between 920 and $1560 \mathrm{mg} \mathrm{Ca}(\mathrm{OH})_{2}$ / g metakaolin.

From the seven experimental metakaolins produced between $750{ }^{\circ} \mathrm{C}$ and $940{ }^{\circ} \mathrm{C}$, a material with modified Chapelle pozzolanic activity value of $1240 \mathrm{mg} \mathrm{Ca}(\mathrm{OH})_{2} / \mathrm{g}$ metakaolin was obtained, which is similar to some tested commercial metakaolins produced at industrial scale.

The metakaolin produced at $800^{\circ} \mathrm{C}$ was ground, resulting in a particle size reduction of $\approx 4 \mathrm{x}$ less and a consequent increase of $21 \%$ in the pozzolanic activity.
\end{abstract}

\section{INTRODUCTION}

Pozzolan is a fine inorganic material composed mainly by rich siliceous or silico-aluminous amorphous phases, which itself possess lower or no binder properties, but in the presence of water, at ordinary temperature and pressure, will chemically react with calcium hydroxide to produce compounds with binder properties.

Pozzolans are raw materials available worldwide and used for the production of blended system composites, as partial replacement of binder (cement or lime) in mortars and in concrete. These materials can be exploited like a georesource (natural source) or obtained from an industrial process (artificial source), usually from a by-product.

The ancient mortars from historic periods were based on the use of lime and in many of them pozzolans, namely natural siliceous volcanic material, were incorporated. In the ancient construction systems of the Mediterranean, since 1500 BC, Greeks used a siliceous volcanic material from Santorini (Moropoulou et al., 2004) and Romans, since the II century BC, used pozzolans extensively (Lancaster, 2005). Vitruvius (c. 16-27 BC) and Seneca (c. 62$65 \mathrm{AC}$ ), reported empirically that pozzolan provides hydraulicity to lime mortar in wet conditions or underwater, and Pliny (c. 77-79 AC) wrote that pozzolans increase the durability of lime mortar. Until the end of the XVIII century, the Italian architects (XV to XVIII centuries) have generally used the Vitruvius's empirical knowledge, without significantly developments about the formulation of mortars with pozzolans and the research of their behaviour. The applied research concerning these subjects got an expressive increment since the end of XVIII century to the first half of XIX century (Sala et al., 2008).

A wide range of test methods to assess the pozzolanic activity of materials have been developed. According to Donatello et al. (2010), these methods can be categorized as either direct or indirect. The first evaluate the presence of $\mathrm{Ca}(\mathrm{OH})_{2}$, using analytical methods such as X-ray diffraction (XRD), thermogravimetric analysis (TGA) or classical chemical titration. The second ones measure a physico-mechanical property on a probe that indicates the extent of pozzolanic activity. This may involve measurement of properties such as mechanical strength, electrical conductivity or heat evolution by conduction calorimetry.

Fratini (1950) pioneered in the development of a laboratorial methodology for the assessment of 
Table 1 Materials used in this study.

\begin{tabular}{lccc}
\hline Sample & Origin & Designation & Description \\
\hline Kaolin & Portugal & Kaolin & Raw material \\
\hline Optipozz & USA & Optipozz & \\
PoleStar 450 & USA & PoleStar 450 & \\
Argical M1200S & France & M1200S & Commercial metakaolin \\
Argical M1000 & France & M1000 & \\
HP & Brazil & HP & \\
BZ & Brazil & BZ & \\
\hline Metakaolin produced at $750^{\circ} \mathrm{C}$ & - & MK-750 & \\
Metakaolin produced at $800^{\circ} \mathrm{C}$ & - & MK-800 & \\
Ground metakaolin produced at $800^{\circ} \mathrm{C}$ & - & MK-800-M & \\
Metakaolin produced at $830^{\circ} \mathrm{C}$ & - & MK-830 & \\
Metakaolin produced at $840^{\circ} \mathrm{C}$ & - & MK-840 & \\
Metakaolin produced at $850^{\circ} \mathrm{C}$ & - & MK-850 & \\
Metakaolin produced at $900^{\circ} \mathrm{C}$ & - & MK-900 & \\
Metakaolin produced at $940^{\circ} \mathrm{C}$ & - & MK-940 & \\
\hline
\end{tabular}

pozzolanic activity, based on the evaluation of the $\mathrm{OH}^{-}$and $\mathrm{Ca}^{2+}$ concentrations presented in a mixture of Portland cement and pozzolan. The "Fratini test" is the basis of the actual EN 196-5 standard. In opposition to Fratini methodology, Chapelle (1958) developed a pseudo-dynamic test to evaluate the activity of a pozzolanic material, based on the consumption of $\mathrm{Ca}(\mathrm{OH})_{2}$ in a saturated water medium. Benoit (1967) improved the Chapelle methodology, particularly in terms of temperature $\left(90^{\circ} \mathrm{C}\right)$ and duration $(16 \mathrm{~h})$ of the test, using $1 \mathrm{~g}$ of pozzolan, $1 \mathrm{~g}$ of calcium oxide and $100 \mathrm{ml}$ of destiled water and gave the denomination "Chapelle test" to this methodology. Largent (1978) criticizing the "Fratini test", because the system does not reach equilibrium and is performed in a static environment, introduced modifications to the Chapelle test, namely the continuous stirring during the duration of the test, and renamed the methodology to "modified Chapelle test".

One of the most worldwide used pozzolanic material is the calcined kaolin (metakaolin), namely used as supplementary cimentitious material. Mitra and Bhattacherjee (1969), Slade et al. (1992), Bellotto et al. (1995), Salvador (1995), He et al. (1995), Pera and Amrouz (1998), Morsy et al. (1998), Kakali et al. (2001), Dion et al. (1998), Chandrasekhar and Ramaswamy (2002), Shvarzman et al. (2003), Souza and Molin (2005), Badogiannis et al. (2005), Bich et al. (2009), Gutierrez et al. (2008), Velosa et al. (2009), Ilić et al. (2010), Vizcayno et al. (2010), Tironi et al. (2012) and Fabbri et al. (2013) reported the influence of mineralogy, particle size distribution, moisture of the raw material, temperature and time of calcination, technique of calcination and the origin of the raw material (natural kaolinitic clay or industrial kaolinitic by-product) in order to obtain metakaolinized materials.

The aim of this study was to assess the pozzolanic activity of commercial and experimental metakaolins through the French standard for the modified Chapelle test (NF P18-513). This direct methodology performed in a aqueous lime-metakaolin system, during 16 hours at $90{ }^{\circ} \mathrm{C}$ with continuous stirring, allows the quantification of portlandite fixed by the metakaolin.

\section{MATERIALS AND METHODS}

The materials used in this study are presented in Table 1. The kaolin raw material (referred as "Kaolin") use in the production of the experimental metakaolins was provided from an industrial Portuguese sand wash plant. Six commercial metakaolins were taken in consideration to compare and serve as reference to the parameters evaluated in this study. Seven experimental metakaolins (referred as "MK") were produced from $750{ }^{\circ} \mathrm{C}$ to $940{ }^{\circ} \mathrm{C}$ (referred as "MK-750" to "MK-940"). The experimental metakaolin produced at $800{ }^{\circ} \mathrm{C}$ (MK800) was intentionally subjected to a grinding process to obtain a ground metakaolin (referred as "MK-800M"). Overall, one kaolin raw material, six commercial metakaolins, seven experimental metakaolins and one milled (ground) experimental metakaolin were considered for analysis.

The kaolin was subjected to mineralogical, chemical, particle size and thermal characterization.

The mineralogical analysis, carried out on nonoriented powder sample, was performed on a Philips X'Pert PRO MPD diffractometer using the X-ray diffraction (XRD) technique, operating with $\mathrm{CuK} \alpha$ radiation at $50 \mathrm{kV}$ and $30 \mathrm{~mA}$. The intensity was determined by counting with a scan rate $0.02^{\circ} \theta / \mathrm{s}$ in the range $4-60^{\circ} 2 \theta$. The identification of the crystalline phases was made by comparison with the Powder Diffraction Files (PDF) from the International Centre for Diffraction Data (ICDD) files. 


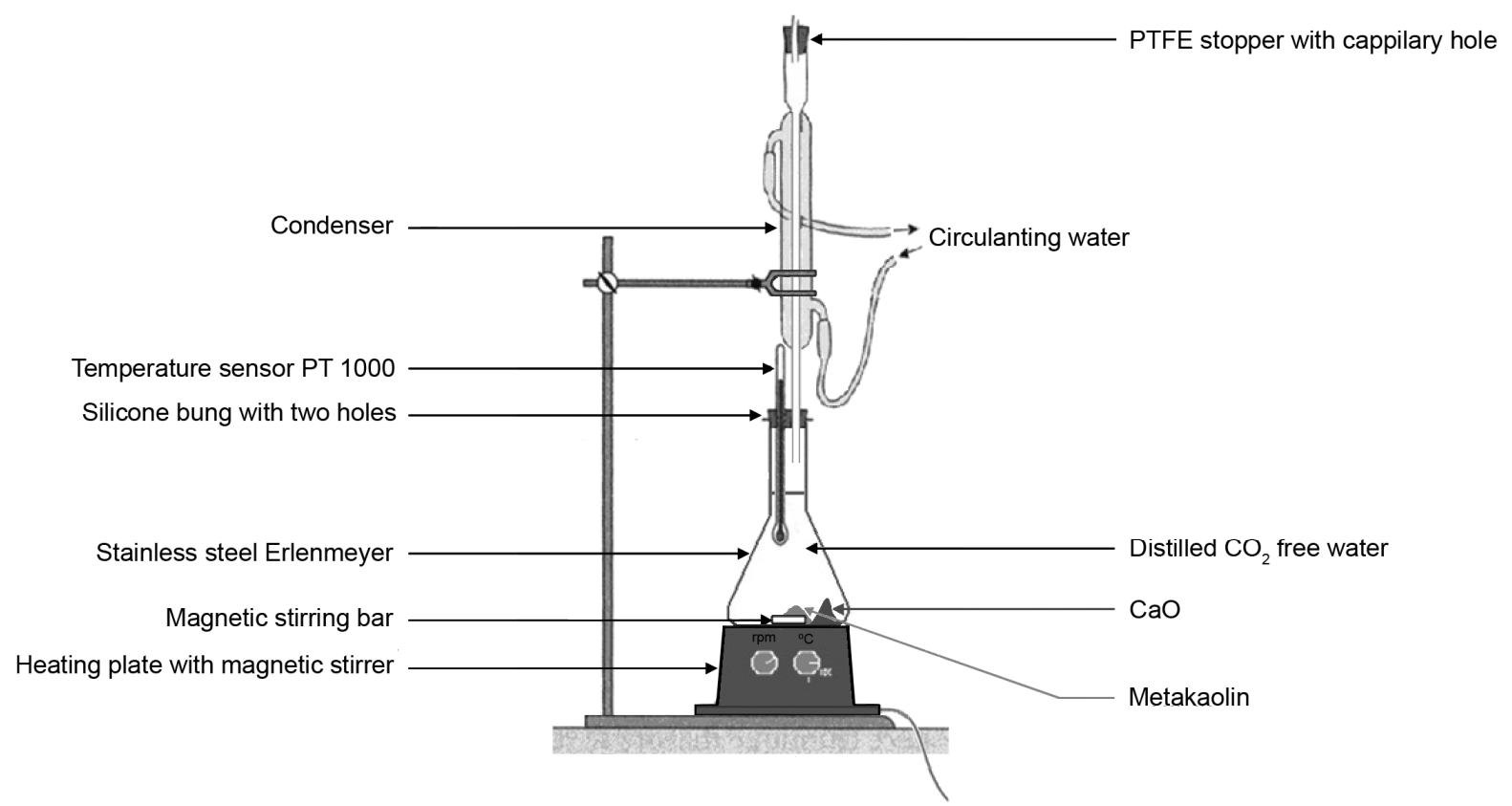

Fig. 1 Assembly of the modified Chapelle test equipment (adapted from NF P18-513, 2010).

Chemical analysis of the major elements was determined by X-ray fluorescence (XRF) spectrometry using a PANalytical equipment PW 4400/40 Axios, with CrK $\alpha$ radiation at $50 \mathrm{kV}$ and 20 $\mathrm{mA}$. A fused pearl with ratio 1 sample / 9 flux (Spectromelt A12) was performed. The loss on ignition was determined by gravimetric analysis, calcinating the sample in a Carbolite CSF 1200 electric furnace at $1000{ }^{\circ} \mathrm{C}$ during 3 hours at maximum temperature in oxidizing ambient atmosphere.

Particle size analysis (PSA) was evaluated by sedimentation and absorption of X-rays in a Micromeritics Sedigraph 5100 apparatus, according to BS 3406-2 standard. The determination was performed on the 0.1 and $63.0 \mu \mathrm{m}$ size range.

Thermogravimetric analysis (TGA) and differential thermal analysis (DTA) were performed using the simultaneous thermal analysis (STA) on a Netzsch Jupiter STA 449 apparatus, with oxidizing atmosphere, between $20{ }^{\circ} \mathrm{C}$ and $1000{ }^{\circ} \mathrm{C}$ and heating rate of $10^{\circ} \mathrm{C} / \mathrm{min}$, according to DIN 51006 and DIN 51007 standards.

The calcination of kaolin was performed on a $2.5 \mathrm{~m}$ scale prototype rotary kiln.

The characterization of the obtained experimental metakaolinized samples (MK-750 to MK940) includes mineralogical, chemical and particle size analysis in accordance with the methodology described for kaolin raw material.

The pozzolanic activity of metakaolins was assessed with the modified Chapelle test according to NF P18-513 standard (annex A). This test allows the quantification of $\mathrm{Ca}(\mathrm{OH})_{2}$ fixed (consumed) by $1 \mathrm{~g}$ of metakaolin when mixed with $2 \mathrm{~g}$ of $\mathrm{CaO}$ and $250 \mathrm{ml}$ of distilled $\mathrm{CO}_{2}$ free water. The suspension was boiled at $90{ }^{\circ} \mathrm{C}$ during $16 \mathrm{~h}$ with continuously stirring in a stainless steel $500 \mathrm{ml}$ Erlenmeyer (Figure 1).

After finished the test time, the Erlenmeyer was cooled to ambient temperature with tap water. The portlandite content that was not consumed (free in solution) was determined by sucrose extraction and acid titration. For that, $250 \mathrm{ml}$ of fresh sucrose solution $(0.7 \mathrm{M})$ were added to the solution, which was stirred with the magnetic bar during $15 \mathrm{~min}$. $200 \mathrm{ml}$ of the final solution were filtrated and taken $25 \mathrm{ml}$ to titrate with $\mathrm{HCl} 0.1 \mathrm{~N}$ with 2-3 drops of phenolphthalein $(0.1 \mathrm{w} / \mathrm{v} \%$ in ethanol $50 \mathrm{v} / \mathrm{v} \%)$. The titration reactions are: $\mathrm{CaO}+2 \mathrm{HCl} \rightarrow \mathrm{CaCl}_{2}+\mathrm{H}_{2} \mathrm{O}$ and $\mathrm{Ca}(\mathrm{OH})_{2}+2 \mathrm{HCl} \rightarrow \mathrm{CaCl}_{2}+2 \mathrm{H}_{2} \mathrm{O}$. The pozzolanic activity of metakaolin is calculated according the formula:

$$
\mathrm{PAM}=2 \frac{\mathrm{V}_{1}-\mathrm{V}_{2}}{\mathrm{~V}_{1}} \frac{74}{56} 1000
$$

PAM - pozzolanic activity of metakaolin, expressed in $\mathrm{mg} \mathrm{Ca}(\mathrm{OH})_{2}$ fixed / $\mathrm{g}$ metakaolin;

$\mathrm{V}_{1}$ - volume of $\mathrm{HCl} 0.1 \mathrm{~N}$, expressed in ml, necessary for titrate $25 \mathrm{ml}$ of the final solution obtained without metakaolin (blank test);

$\mathrm{V}_{2}$ - volume of $\mathrm{HCl} 0.1 \mathrm{~N}$, expressed in $\mathrm{ml}$, necessary for titrate $25 \mathrm{ml}$ of the final solution obtained with metakaolin.

The blank test (without metakaolin) must verify $\mathrm{V}_{1} \frac{56}{2}<1000$ and the repeatability of the modified Chapelle test is $10 \%$ for $1100 \mathrm{mg} \mathrm{Ca}(\mathrm{OH})_{2}$ fixed / $\mathrm{g}$ metakaolin. 


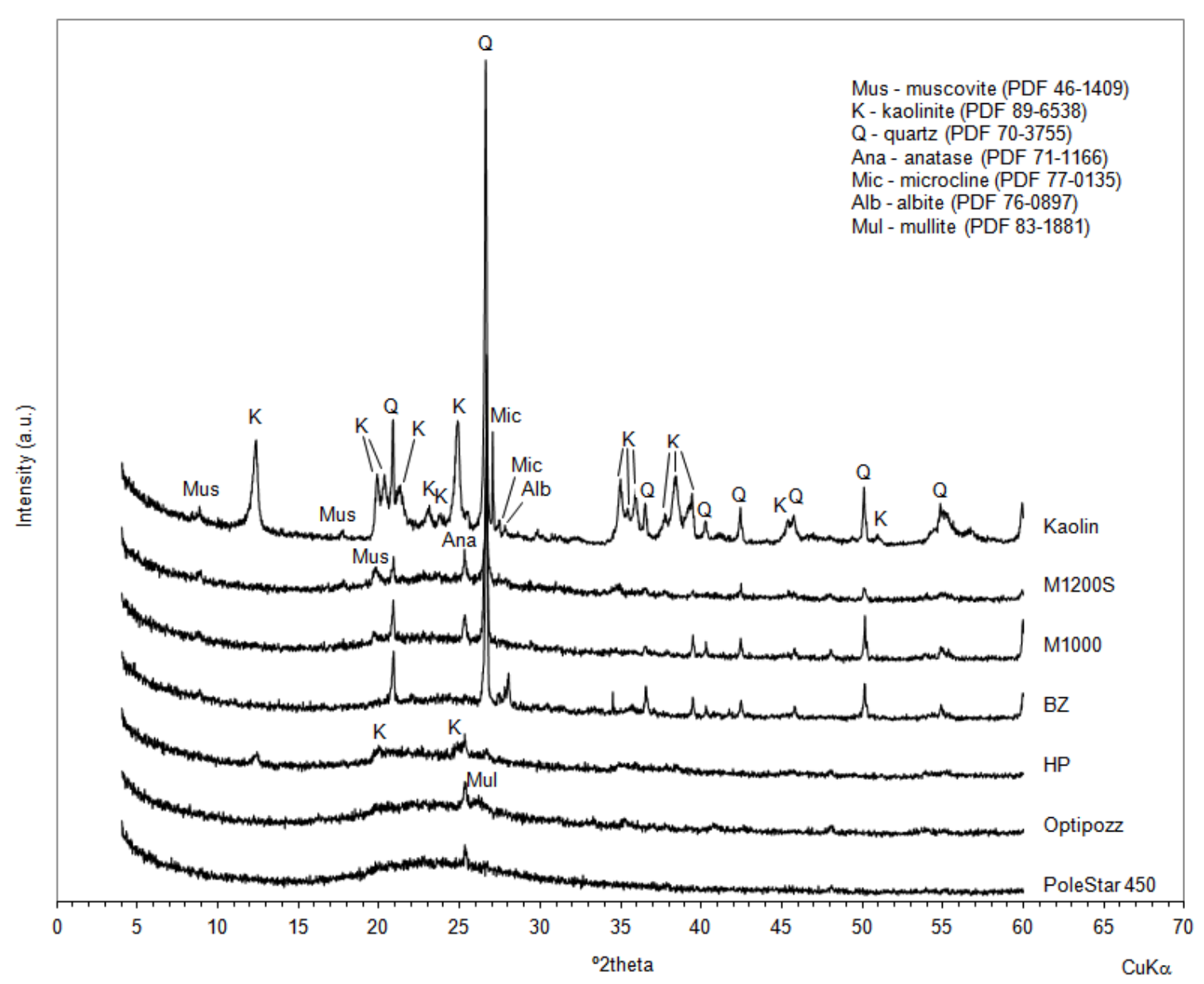

Fig. 2 XRD patterns of the kaolin raw material and commercial metakaolins.

Specific surface area of the metakaolins was determined in a Micromeritics Gemini 2.0 instrument, using the BET method (Brunauer et al., 1938). Samples were pre-treated at $200{ }^{\circ} \mathrm{C}$ under a nitrogen flow before measurements were made.

The cation exchange capacity (CEC) of the metakaolins was evaluated by the classic ammonium acetate saturation method following the procedure of Cowan and White (1958) and the calculations of Chapman (1965).

The morphology of the particles was observed by scanning electron microscopy (SEM) using a Hitachi S4100 electron microscope. The samples were previously subjected to coated carbon deposition carried out on an Emitech K950X equipment.

A soft disaggregation carried out with an alumina ball mill (Gabbrielli Fast Mill) during 5 minutes on aggregate experimental metakaolins was accomplished. The milling of one experimental metakaolin was accomplished in a vibratory agate disc mill (Retsch RS1) during 20 minutes at $700 \mathrm{rpm}$.

The properties of the experimental metakaolin samples were compared with the commercial metakaolins.

\section{RESULTS AND DISCUSSION \\ 3.1. KAOLIN}

Mineralogical analysis of the kaolin is presented in Figure 2. As expected, quartz and kaolinite are present as major minerals. As accessory minerals muscovite (mica), microcline (alkali feldspar) and albite (plagioclase) were identified.

The chemical composition (Table 2) of the kaolin shows higher values for silicon oxide (56.8\%) and aluminium oxide (30.7\%) which are mainly related with quartz and kaolinite minerals. The high value for potassium oxide $(1.5 \%)$ is connected with the occurrence of microcline and muscovite. The non quantification content of sodium oxide below the quantification limit of the XRF technique could reflects the vestigial amount of plagioclase discriminated on XRD pattern. Values for iron $(0.9 \%)$, magnesium $(0.2 \%)$ and titanium $(0.3 \%)$ oxides are connected with the exchanged cations presented in kaolinite crystallochemical structure, as well as to the presence of muscovite (iron and magnesium) as a penalizing mineral. The loss on ignition value $(9.9 \%)$ corroborates the presence of kaolinite (Figure 2 ) as main clay mineral. 
Table 2 Chemical composition of the kaolin raw material and commercial metakaolins.

\begin{tabular}{lcrrrrrr}
\hline $\begin{array}{l}\text { Oxides } \\
(\%)\end{array}$ & $\begin{array}{c}\text { Kaolin raw } \\
\text { material }\end{array}$ & Optipozz & $\begin{array}{c}\text { PoleStar } \\
450\end{array}$ & M1200S & M1000 & BZ & HP \\
\hline $\mathrm{SiO}_{2}$ & 56.84 & 51.93 & 52.18 & 54.39 & 57.13 & 59.59 & 50.03 \\
$\mathrm{Al}_{2} \mathrm{O}_{3}$ & 30.70 & 44.94 & 45.48 & 39.36 & 34.20 & 31.39 & 42.62 \\
$\mathrm{Fe}_{2} \mathrm{O}_{3}$ & 0.89 & 0.44 & 0.47 & 1,75 & 1.15 & 4.45 & 2.17 \\
$\mathrm{MnO}$ & 0.01 & nd & nd & 0.01 & 0.01 & 0.04 & 0.01 \\
$\mathrm{MgO}$ & 0.16 & 0.01 & 0.02 & 0.16 & 0.23 & 0.45 & 0.18 \\
$\mathrm{CaO}$ & 0.05 & 0.01 & 0.03 & 0.10 & 0.10 & 0.87 & 0.01 \\
$\mathrm{Na}_{2} \mathrm{O}$ & nd & nd & nd & nd & nd & 0.21 & nd \\
$\mathrm{K}_{2} \mathrm{O}$ & 1.53 & 0.14 & 0.09 & 1.03 & 0.49 & 0.82 & 0.53 \\
$\mathrm{TiO}_{2}$ & 0.27 & 1.39 & 0.97 & 1.55 & 1.91 & 0.67 & 1.39 \\
$\mathrm{P}_{2} \mathrm{O}_{5}$ & 0.04 & 0.12 & 0.08 & 0.06 & 0.04 & 0.23 & 0.04 \\
$\mathrm{LOI}$ & 9.85 & 1.23 & 0.93 & 1.90 & 5.00 & 1.30 & 3.37 \\
\hline
\end{tabular}

LOI: loss on ignition, nd: less quantification limit

Particle size distribution for kaolin present very fine particle size $(\mathrm{d} 50=1.5 \mu \mathrm{m})$ which results from the origin of the material (industrial sand washing) and BET specific surface area of $19.0 \mathrm{~m}^{2} / \mathrm{g}$.

The thermogravimetric behaviour of the kaolin presented two weight losses, the first $(0.6 \%)$ at $80{ }^{\circ} \mathrm{C}$ attributed to the remove of moisture, and the second loss $(10 \%)$ that occurred between $400{ }^{\circ} \mathrm{C}$ and $950{ }^{\circ} \mathrm{C}$ due to the dehydroxylation of the clay minerals (kaolinite and mica). The weight loss of $10 \%$ corroborates the value of $9.9 \%$ obtained for the loss on ignition (Table 2).

Concerning the thermodifferential behaviour, there was one endothermic peak at $\approx 72{ }^{\circ} \mathrm{C}$, which is due to the release of moisture and another endothermic peak at $\approx 536{ }^{\circ} \mathrm{C}$, which represents the maximum temperature of dehydroxylation. There is also an exothermic peak at $\approx 996{ }^{\circ} \mathrm{C}$ due to the formation of primary mullite. In summary, it can be noted that the process of dehydroxylation of the kaolinite, which leads to the transformation into metakaolinite, occurs at a wide temperature range from $400{ }^{\circ} \mathrm{C}$ to $950{ }^{\circ} \mathrm{C}$.

\subsection{COMMERCIAL METAKAOLINS}

The mineralogical analysis of commercial metakaolins (Figure 2) present penalizing minerals, such as, muscovite, quartz and feldspar that can be observed on M1200S, M1000 and BZ metakaolins. Also is evident in all metakaolins (except BZ) the presence of anatase $\left(\mathrm{TiO}_{2}\right)$. The HP metakaolin presents a rest of non calcined kaolinite. The Optipozz metakaolin denotes the presence of mullite, indicating that this material was calcined at a temperature near the uppermost limit $\left(\approx 1000^{\circ} \mathrm{C}\right)$. In all metakaolins, a wide convexity with low intensity, developed between $\approx 15-30$ degrees $\left({ }^{\circ} 2 \theta\right)$ is noticeable, attributed to the discrimination of the amorphous phase (metakaolinite).

HP $(19.1 \mu \mathrm{m}), \mathrm{BZ}(11.5 \mu \mathrm{m})$ and M1000 $(8.2 \mu \mathrm{m})$ metakaolins show coarser $\mathrm{d} 50$ grain distribution when compared with the remnant studied metakaolins. The Optipozz, PoleStar 450 and M1200S metakaolins presents fine grain distribution, with $\mathrm{d} 50$ range between 1.1 and $1.8 \mu \mathrm{m}$ (Table 3 ).

The chemical elemental analysis of commercial metakaolins is shown in Table 2. No significant differences between commercial metakaolins were found, but some facts must be evidenced: i) relatively high content of titanium oxide related with the presence of anatase; ii) the potassium oxide content of $1.0 \%(\mathrm{M} 1200 \mathrm{~S})$ and $0.8 \%(\mathrm{BZ})$ is related with the alkali feldspar presented in both metakaolins; iii) the calcium oxide content $(0.9 \%)$ observed in the BZ metakaolin is due to the presence of plagioclase; iv) both BZ and HP metakaolins presented the highest iron oxide values, $4.5 \%$ and $2.2 \%$, respectively, which can be related with iron oxide minerals as contaminants; v) the loss on ignition values of $5.0 \%$ (M1000), $3.4 \%$ (HP), $1.9 \%$ (M1200S) and $1.3 \%$ (BZ) are related with the muscovite and for HP also with the remaining kaolinite that was not transformed into metakaolinite (Figure 2); vi) the values observed for silicon and aluminium oxides are mainly correlated with the metakaolinite content and with mullite in Optipozz material.

According to the modified Chapelle test (Table 3), the Optipozz and PoleStar 450 metakaolins exhibit higher pozzolanic activity values, 1560 and $1550 \mathrm{mg}$ $\mathrm{Ca}(\mathrm{OH})_{2}$ / g metakaolin, respectively. The BZ metakaolin showed the lowest value $\left(920 \mathrm{mg} \mathrm{Ca}(\mathrm{OH})_{2}\right.$ / g metakaolin). Optipozz metakaolin present the higher value of modified Chapelle pozzolanic activity. This material is classified as "high reactive metakaolin" in cimentitious systems (Antoni et al., 2012). The NF P 18-513 standard defines that the pozzolanic activity of a metakaolin should not be less than $700 \mathrm{mg} \mathrm{Ca}(\mathrm{OH})_{2} / \mathrm{g}$ metakaolin.

The morphology of the particles presented in the commercial metakaolins can be observed in Figure 3. The calcined kaolinite particles in the Optipozz metakaolin (highest pozzolanic activity material) 
Table 3 Physico-chemical properties and characteristics of the commercial and experimental metakaolins.

\begin{tabular}{lcccc}
\hline Sample & $\begin{array}{c}\mathrm{d} 50 \\
(\mu \mathrm{m})\end{array}$ & $\begin{array}{c}\text { Pozzolanic activity } \\
\left(\mathrm{mg} \mathrm{Ca}(\mathrm{OH})_{2} / \mathrm{g} \text { metakaolin }\right)\end{array}$ & $\begin{array}{c}\text { Specific surface } \\
\text { area }\left(\mathrm{m}^{2} / \mathrm{g}\right)\end{array}$ & $\begin{array}{c}\text { Cation exchange capacity } \\
(\mathrm{cmol} / \mathrm{kg})\end{array}$ \\
\hline \multicolumn{2}{l}{ Commercial metakaolin } & & & 9.9 \\
\hline Optipozz & $1.8^{*}$ & 1560 & $17.9^{*}$ & 3.9 \\
PoleStar 450 & 1.2 & 1550 & 14.7 & 3.7 \\
M1200S & 1.1 & 1320 & 21.7 & 3.0 \\
M1000 & 8.2 & 1190 & 14.9 & 4.1 \\
HP & 11.5 & 1120 & 23.6 & 7.6 \\
BZ & 19.1 & 920 & 12.6 & 6.1 \\
\hline Experimental metakaolin & $8.3^{*}$ & & & 7.6 \\
\hline MK-750 & 8.4 & 910 & $16.3^{*}$ & 38.5 \\
MK-800 & 2.2 & 1150 & 9.6 & 6.7 \\
MK-800-M & 8.7 & 990 & 11.8 & 7.8 \\
MK-830 & $7.7^{*}$ & 1030 & 5.6 & 9.4 \\
MK-840 & 4.5 & 1180 & $9.8 *$ & 6.3 \\
MK-850 & 9.2 & 910 & 10.9 & 9.9 \\
MK-900 & $3.5^{*}$ & 1240 & 9.1 & $9.7^{*}$ \\
MK-940 & & & \\
\hline
\end{tabular}

* Gamelas et al. (2014)
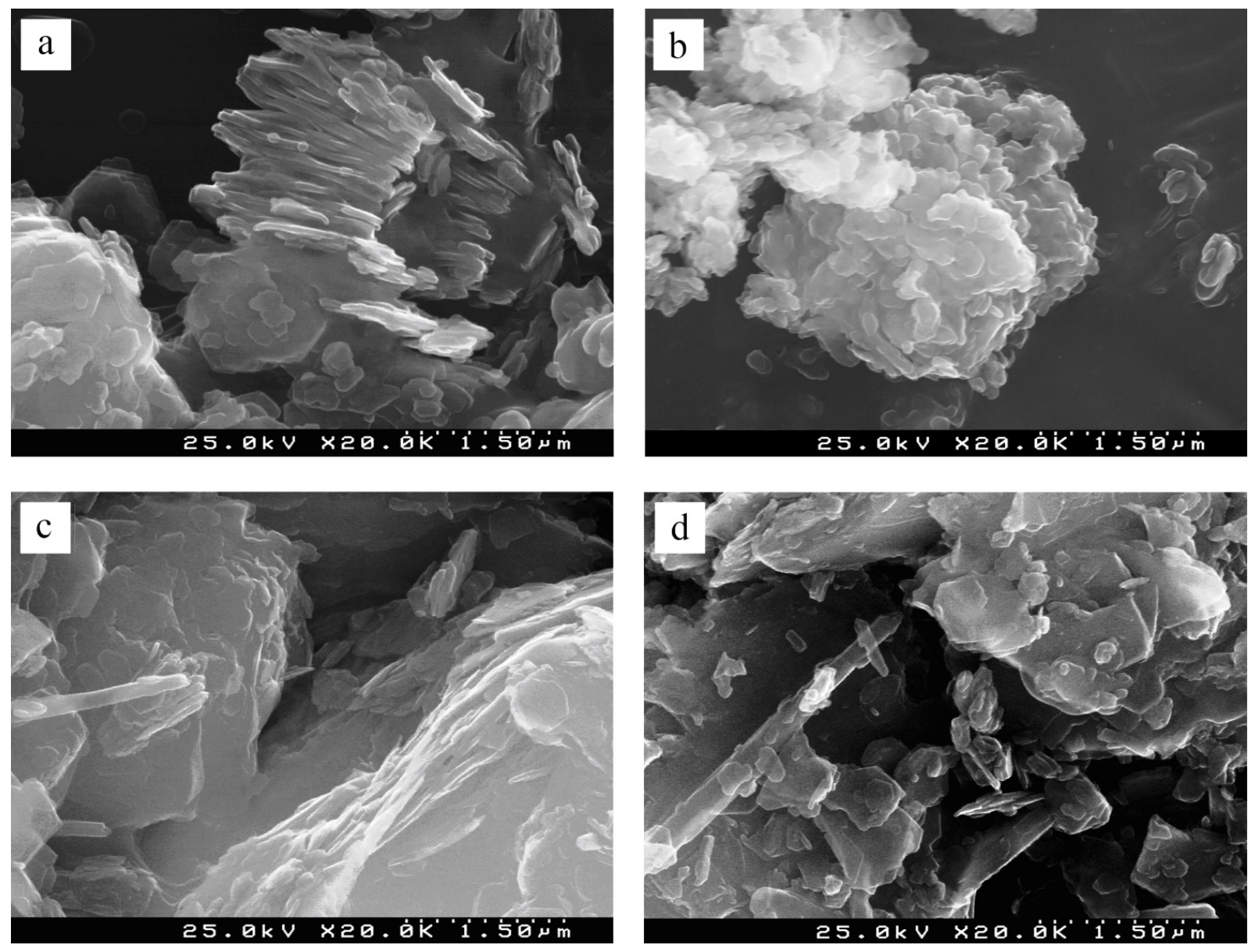

Fig. 3 SEM microphotographs of the metakaolins: a) Optipozz; b) BZ; c) MK-750; d) MK-940. 


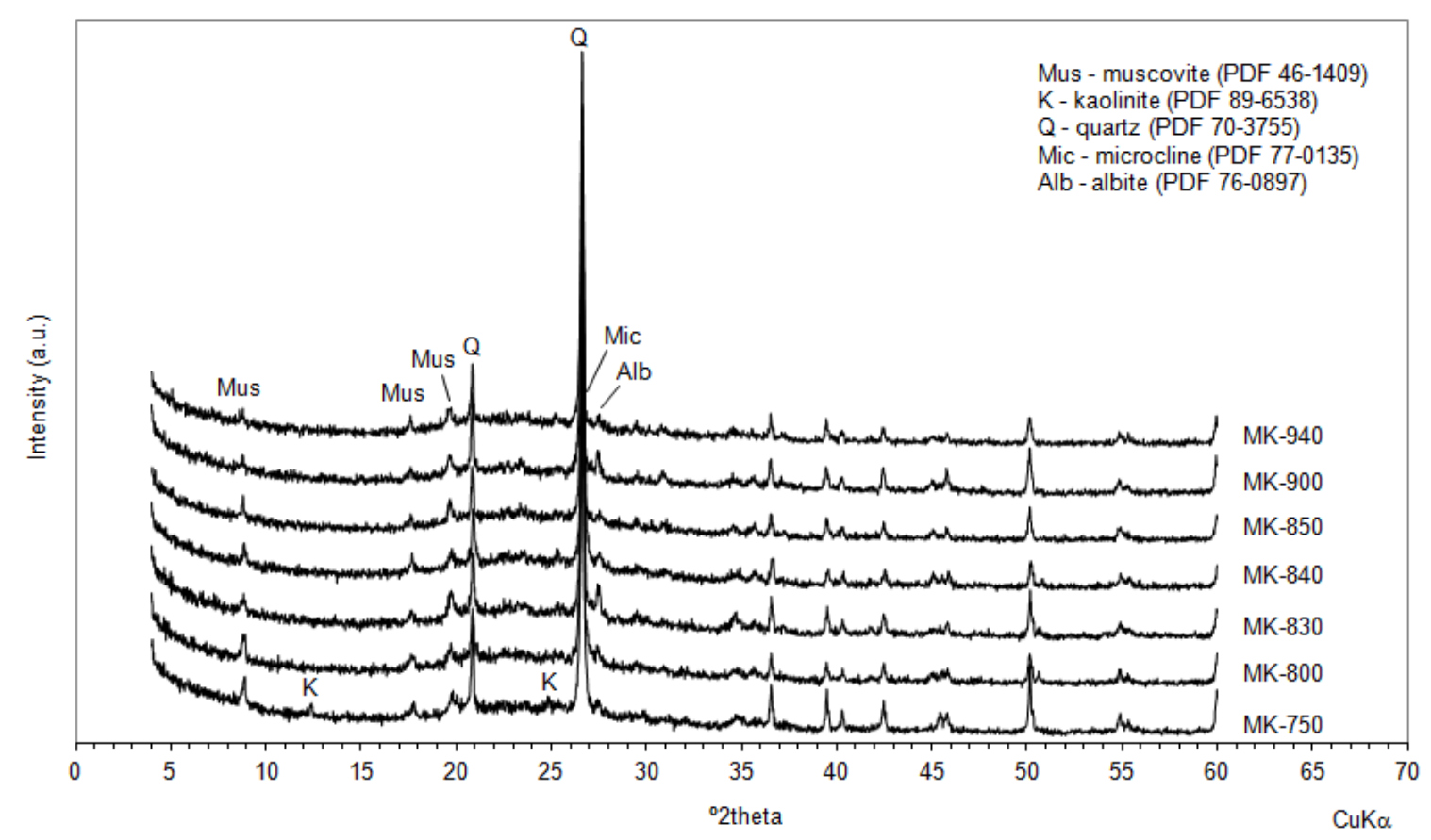

Fig. 4 XRD patterns of the experimental metakaolins.

Table 4 Experimental conditions for the production of experimental metakaolins.

\begin{tabular}{lccccl}
\hline Sample & $\begin{array}{c}\text { Input particle } \\
\text { size }\end{array}$ & $\begin{array}{c}\text { Input moisture } \\
\text { content }\end{array}$ & $\begin{array}{c}\text { Kiln } \\
\text { temperature } \\
\left({ }^{\circ} \mathrm{C}\right)\end{array}$ & $\begin{array}{c}\text { Calcination } \\
\text { time }(\mathrm{h}: \mathrm{min})\end{array}$ & $\begin{array}{c}\text { Processing after } \\
\text { calcination }\end{array}$ \\
\hline MK-750 & Powder & $\approx 2 \%$ & 750 & $\approx 1: 05$ & - \\
MK-800 & Powder & $\approx 2 \%$ & 800 & $\approx 1: 30$ & - \\
MK-830 & $\approx 1.5 \mathrm{~cm}$ & $\approx 16 \%$ & 830 & $\approx 2: 25$ & Soft disaggregation \\
MK-840 & Powder & $\approx 2 \%$ & 840 & $\approx 1: 05$ & - \\
MK-850 & $\approx 1.5 \mathrm{~cm}$ & $\approx 16 \%$ & 850 & $\approx 1: 05$ & Soft disaggregation \\
MK-900 & $\approx 1.5 \mathrm{~cm}$ & $\approx 16 \%$ & 900 & $\approx 2: 25$ & Soft disaggregation \\
MK-940 & $\approx 1.5 \mathrm{~cm}$ & $\approx 16 \%$ & 940 & $\approx 1: 05$ & Soft disaggregation \\
\hline
\end{tabular}

preserves the pseudo-hexagonal shape of the original kaolinite morphology with pseudo regular shape and pseudo angular borders (Figure 3a) by opposition to the BZ metakaolin (lowest pozzolanic activity material) that present roundness and smoothing particles (Figure 3b). In this sense, the shape of the calcined kaolinite particle can have some influence in the pozzolanic activity of the commercial metakaolins.

The d50 particle size values for the commercial metakaolins denounce an interesting correlation with the modified Chapelle results expressed by an inverse linear trend (modified Chapelle $=-32.032 \times \mathrm{d} 50+$ 1505.700, $\left.\mathrm{R}^{2}=0.8551\right)$. The $\mathrm{d} 50$ results for $\mathrm{M} 1200 \mathrm{~S}$ $(1.1 \mu \mathrm{m})$, PoleStar $450(1.2 \mu \mathrm{m})$ and Optipozz $(1.8 \mu \mathrm{m})$ presents the lowest values for the studied metakaolins. This allows to infer that at least these commercial metakaolins are subjected to an intense milling stage.
Concerning SSA and CEC results obtained on commercial metakaolins, it was not found mathematical correlations to modified Chapelle pozzolanic activity.

\subsection{EXPERIMENTAL METAKAOLINS}

The parameters for the production of experimental metakaolins are shown in Table 4. The experimental calcination temperatures established in the rotary kiln were restricted between $750{ }^{\circ} \mathrm{C}$ and $940{ }^{\circ} \mathrm{C}$, since according the STA analysis, the dehydroxilation of the kaolinite occurs from $400{ }^{\circ} \mathrm{C}$ to $900{ }^{\circ} \mathrm{C}$ Due to the formation of particle aggregates during the calcination process, some of the calcinated materials (MK-830, MK-850, MK-900 and MK-940) were submitted to a soft mechanical disaggregation (Table 4). In order to evaluate the effect of particle size reduction in the modified Chapelle pozzolanic 
activity of the experimental metakaolins, the metakaolin produced at $800{ }^{\circ} \mathrm{C}(\mathrm{MK}-800)$ was milled to obtain one ground metakaolin (MK-800-M).

The mineralogical analysis of the seven experimental metakaolins is discriminated in Figure 4. In addition to the initial penalizing minerals (muscovite, quartz and feldspars) presented in the kaolin, the presence of kaolinite that has not been fully calcinated (metakaolinized) was identified in the MK-750 metakaolin, due to the calcination at the lowest temperature $\left(750^{\circ} \mathrm{C}\right)$. The limit for calcination temperature was not reached, since the presence of mullite in MK-940 metakaolin was not identified (Figure 4). However at this temperature, it is possible the formation of vestigial cubic, spinel or gammaalumina phase undetected in XDR pattern.

All the experimental metakaolins presented a narrow particle size range, except for MK-800-M metakaolin that was submitted to a purposeful comminution process. There were no significant differences in $\mathrm{d} 50$ between samples that did not undergo disaggregation after calcination (MK-750, MK-800 and MK-840) (Tables 3 and 4). As referred, the MK-800-M sample was submitted to a particle size reduction and by this way present the finest particle size of the experimental samples $(\mathrm{d} 50=2.2 \mu \mathrm{m})$. The disaggregated samples MK-850 and MK-940 presents lower particle size with $\mathrm{d} 50=4.5 \mu \mathrm{m}$ and $\mathrm{d} 50=3.5 \mu \mathrm{m}$, respectively.

For an efficient calcination of the kaolinite material, the $\mathrm{d} 50$ of the calcinated material is a crucial parameter for a better pozzolanic behaviour. The influence of particle size in the reactivity of metakaolins is reported by Oliveira et al. (2005).

The physicochemical parameters evaluated in the experimental metakaolins are presented in Table 3. The increase of calcination temperature from MK-750 to MK-940 metakaolin (except for MK-900) was responsible for the increase of the modified Chapelle pozzolanic activity.

When compared with MK-850 metakaolin, the decrease in modified Chapelle pozzolanic activity on MK-900 could be related with the increase in $\mathrm{d} 50$, the decrease of CEC and higher duration of calcination.

The effect of particle size reduction in the calcinated product is a key factor for the increase of the modified Chapelle pozzolanic activity, as can be observed from MK-800 to MK-800-M samples. The MK-800 sample was submitted to a grinding process, which has resulted in a consequent reduction $(\approx 4 \mathrm{x}$ less) of the particle size from $8.4 \mu \mathrm{m}$ to $2.2 \mu \mathrm{m}$ (Table 3) and a consequent increase in the specific surface. With this additional process a relative gain of $21 \%$ in the modified Chapelle pozzolanic activity was obtained. This fact is directly related with the comminution of metakaolins, which promotes a surface particle with less nanorough and increase the Lewis basic properties of the surface on the ground metakaolinitic particles (Gamelas et al., 2014).
Contrary to the trend observed on commercial metakaolins, on experimental metakaolins the modified Chapelle results presents lower correlation with particle size $(\mathrm{d} 50)$ results (modified Chapelle $=$ $\left.-41.624 \times \mathrm{d} 50+1302.500, \mathrm{R}^{2}=0.6561\right)$. This evidence could be related to the relative proximity of the global values. Except MK-800-M, MK-850 and MK-940, the d50 values range from 6.2 to $8.4 \mu \mathrm{m}$, which involves less data discrimination.

As expected, the CEC values of the not ground experimental metakaolins (Table 3) are lower (6.1 to $9.9 \mathrm{cmol}_{\mathrm{c}} / \mathrm{kg}$ ) and with the same order as reported by San Cristóbal (2010) for an industrial sand wash kaolin calcined at $750{ }^{\circ} \mathrm{C}$ for $3 \mathrm{~h}\left(2.4 \mathrm{cmol}_{\mathrm{c}} / \mathrm{kg}\right)$. The ground metakaolin (MK-800-M) shows the higher CEC value $\left(38.5 \mathrm{cmol}_{\mathrm{c}} / \mathrm{kg}\right)$ due to the purposeful grinding stage, which increases CEC at about $400 \%$ when compared with the MK-800 metakaolin $\left(7.6 \mathrm{cmol}_{\mathrm{c}} / \mathrm{kg}\right)$. The modified Chapelle pozzolanic activity obtained on the experimental metakaolins showed a linear trend with CEC (modified Chapelle $=84.311 \times$ cation exchange capacity +382.490$)$ and good correlation $\left(\mathrm{R}^{2}=0.9219\right)$. This correlation was calculated without the ground metakaolin (MK-800$\mathrm{M})$, since there is only one ground result and the obtained value is from an upper order.

For both commercial and experimental metakaolins, it was not observed any correlation to SSA data. Apparently, and contrary to what occurs to CEC, SSA do not have relation with Lewis basic properties of the surface on calcined kaolinite particles. Further studies are in progress on this subject.

The morphology of the particles for the experimental metakaolins do not present notable differences between them (Figures $3 \mathrm{c}$ and 3d). The experimental metakaolins with lower (MK-750) and higher modified Chapelle pozzolanic activity (MK940) presents generically roundness and smoothing calcined kaolinite particles. In fact, the modified Chapelle pozzolanic activity for MK-940 metakaolin (1240 $\mathrm{mg} \mathrm{Ca}(\mathrm{OH})_{2} / \mathrm{g}$ metakaolin) is at the same order (except BZ metakaolin) of the modified Chapelle pozzolanic activity of commercial metakaolins, putting in evidence that the increment in the modified Chapelle pozzolanic activity of the experimental metakaolins is not closely related with shape and geometry of the calcined particle.

\section{CONCLUSIONS}

According the goal of this study and based in the obtained results, discussion and interpretation of the data, the following remarks can be stated about the direct methodology that allows the evaluation of the pozzolanic activity of metakaolins by the French standard of the modified Chapelle test applied to commercial and experimental metakaolins:

- It is an expeditiously methodology, with simple and quick execution allowing the direct 
evaluation (non strength tests) of the pozzolanic activity of metakaolins;

- The modified Chapelle pozzolanic activity of commercial metakaolins presented values between 920 and $1560 \mathrm{mg} \mathrm{Ca}(\mathrm{OH})_{2} / \mathrm{g}$ metakaolin, highlighting the significant differences in the quality of each commercial tested material;

- The values of the modified Chapelle pozzolanic activity obtained in the experimental metakaolins are above the standard limit $\left(700 \mathrm{mg} \mathrm{Ca}(\mathrm{OH})_{2} / \mathrm{g}\right.$ metakaolin);

- The evaluation of the modified Chapelle pozzolanic activity on experimental metakaolins yielding an optimized material with a pozzolanic activity value of $1240 \mathrm{mg} \mathrm{Ca}(\mathrm{OH})_{2} / \mathrm{g}$ metakaolin;

- In commercial metakaolins, the modified Chapelle results has an interesting correlation with particle size (d50);

- In experimental metakaolins, the modified Chapelle results increase with the increase of the cation exchange capacity results. The modified Chapelle pozzolanic activity is independent of the particle morphology. The grinding stage affects significantly the modified Chapelle pozzolanic activity;

- For both commercial and experimental metakaolins, it was not observed any relation either with specific surface area or calcined kaolinite morphology to modified Chapelle pozzolanic activity.

\section{ACKNOWLEDGMENTS}

This research was supported by Sistema de Incentivos à Investigação e Desenvolvimento Tecnológico - Vale I\&DT to Cerâmica Condestável, Lda (Portugal), supported by Quadro de Referência Estratégica Nacional, Research Project METACAL Study of Lime-Metakaolin Mortars for Building Conservation (PTDC/ECM/100431/2008), Research Unit (UID/GEO/04035/2013) and Projecto Estratégico (PEst-OE/CTE/UI4035/2014) financed by the Fundação para a Ciência e a Tecnologia (FCT) and COMPETE - Programa Operacional Factores de Competitividade.

\section{REFERENCES}

Antoni, M., Rossen, J., Martirena, F. and Scrivener, K: 2012, Cement substitution by a combination of metakaolin and limestone. Cement and Concrete Research, 42, Iss. 12, 1579-1589.

DOI: 10.1016/j.cemconres.2012.09.006

Badogiannis, E., Kakali, G. and Tsivilis, S.: 2005, Metakaolin as supplementary cementitious material. Optimization of kaolin to metakaolin conversion. Journal of Thermal Analysis and Calorimetry, 81, Iss. 2, 457-462. DOI: 10.1007/s10973-005-0806-3

Bellotto, M., Gualtieri, A., Artioli, G. and Clark, S.M.: 1995, Kinetic study of the kaolinite-mullite reaction sequence. Part I: Kaolinite dehydroxylation. Physics and Chemistry of Minerals, 22, Iss. 4, 207-217. DOI: $10.1007 / \mathrm{BF} 00202253$

Benoit, O.: 1967, Determination of the pozzolanic activity of a pozzolan by chemical mean. Bulletin de Liaison des Laboratoires des Routiers: Ponts et Chaussées, 26, D1-D5, (in French).

Bich, Ch., Ambroise, J. and Péra, J.: 2009, Influence of degree of dehydroxylation on the pozzolanic activity of metakaolin. Applied Clay Science, 44, Iss. 3-4, 194-200. DOI: 10.1016/j.clay.2009.01.014

Brunauer, S., Emmett, P.H. and Teller, E.: 1938, Adsorption of gases in multimolecular layers. Journal of the American Chemical Society, 60, No. 2, 309-319. DOI: $10.1021 /$ ja01269a023

BS 3406-2: 1986, Methods for determination of particle size distribution: Recommendations for gravitational liquid sedimentation methods for powders and suspensions. British Standard Institute, London.

Chandrasekhar, S. and Ramaswamy, S.: 2002, Influence of mineral impurities on the properties of kaolin and its thermally treated products. Applied Clay Science, 21, Iss. 3-4, 133-142. DOI: $10.1016 / \mathrm{S} 0169-1317(01) 00083-7$

Chapelle, J.: 1958, Sulpho-calcic attack of slags and pozzolans. Revue des Matériaux de Construction et de Travaux Publics. Edition C: Chaux, ciment, plâtre, agglomérés, 511: 87-100, 512: 136-151, 513: 159-170, 514-515: 193-201, 516: 231-242, (in French).

Chapman, H.D.: 1965, Cation-exchange capacity, 891-901. In: Black, C.A. (Ed), Methods of soil analysis, Part 2 Chemical and microbiological properties. American Society of Agronomy and Soil Science Society of America, Madison, WI.

Cowan, C.T. and White, D.: 1958, The mechanism of exchange reactions occurring between sodium montmorillonite and various n-primary aliphatic amine salts. Transaction of the Faraday Society, 54, 691-697. DOI: 10.1039/TF9585400691

DIN 51006: 1990, Principles of thermogravimetry. Deutsches Institut für Normung, Berlin.

DIN 51007: 1994, General principles of differencial thermal analisys. Deutsches Institut für Normung, Berlin.

Dion, P., Alcover, J.-F., Bergaya, F., Ortega, A., Llewellyn, P.L. and Rouquerol, F.: 1998, Kinetic study by controlled-transformation rate thermal analysis of the dehydroxylation of kaolinite. Clay Minerals, 33, No. 2, 269-276. DOI: 10.1180/000985598545624

EN 196-5: 2005, Methods of testing cement. Part 5: pozzolanicity test for pozzolanic cement. Committee for European Standardization, Brussels.

Fabbri, B., Gualtieri, S. and Leonardi, C.: 2013, Modifications induced by the thermal treatment of kaolin and determination of reactivity of metakaolin. Applied Clay Science, 73, Iss. 1, 2-10.

DOI:10.1016/j.clay.2012.09.019

Fernandez, R., Martirena, F. and Scrivener, K.L.: 2011, The origin of the pozzolanic activity of calcined clay minerals: A comparison between kaolinite, illite and montmorillonite. Cement and Concrete Research, 41, Iss. $1,113-122$. DOI: 10.1016/j.cemconres.2010.09.013

Fratini, N.: 1950, Research of hydrolysis lime in cement pastes. Note II. Proposal test for the chemical evaluate of pozzolanic cement. Annali di Chimica, 40, 461469, (in Italian).

Gamelas, J.A.F., Ferraz, E. and Rocha, F.: 2014, An insight into the surface properties of calcined clays: The 
grinding effect. Colloids and Surfaces A: Physicochemical and Engineering Aspects, 455, 4957. DOI: $10.1016 /$ j.colsurfa.2014.04.038

Gutierrez, M.R., Torres, J., Vizcayno, C. and Castelló, R.: 2008, Influence of the calcination temperature of kaolin on the mechanical properties of mortars and concretes containing metakaolin. Clay Minerals, 43, No. 2, 177-183. DOI: 10.1180/claymin.2008.043.2.02

He, C., Osbaeck, B. and Makovicky, E.: 1995, Pozzolanic reactions of six principal clay minerals: Activation, reactivity assessments and technological effects. Cement and Concrete Research, 25, Iss. 8, 1691-1702. DOI: 10.1016/0008-8846(95)00165-4

Ilić, B.R., Mitrović, A.A. and Miličić, L.R.: 2010, Thermal treatment of kaolin clay to obtain metakaolin. Hemijska industrija, 64, Iss. 4, 351-356. DOI: 10.2298/HEMIND100322014I

Kakali, G., Perraki, T., Tsivilis, S. and Badogiannis, E.: 2001, Thermal treatment of kaolin: the effect of mineralogy on the pozzolanic activity. Applied Clay Science, 20, Iss. 1-2, 73-80.

DOI: $10.1016 / \mathrm{S} 0169-1317(01) 00040-0$

Largent, R.: 1978. Estimation the pozzolanic activity: a research test. Bulletin de Liaison des Laboratoires des Routiers: Ponts et Chaussées, 93, 61-65, (in French).

Mitra, G.B. and Bhattacherjee, S.: 1969, X-ray diffraction studies on the transformation of kaolinite into metakaolin: I. variability of interlayer spacings. The American Mineralogist, 54, 1409-1418.

Morsy, M.S., Galal, A.F. and Abo-El-Enein, S.A.: 1998, Effect of temperature on phase composition and microstructure of artificial pozzolana-cement pastes containing burnt kaolinite clay. Cement and Concrete Research, 28, Iss. 8, 1157-1163. DOI: $10.1016 / \mathrm{S} 0008-8846(98) 00083-0$

NF P18-513: 2010, Metakaolin. Pozzolanic addition for concrete. Definitions, specifications and conformity criteria. Association Française de Normalisation, La Plaine Saint-Denis, (in French).

Oliveira, L.A.P., Jalali, S., Fernandes, J.M. and Torres, E., 2005. The use of metakaolin to produce eco-efficient concrete. Materials and Structures, 38, 403-410. DOI: $10.1617 / 14186$ (in French)

Pera, J. and Amrouz, A.: 1998, Development of highly reactive metakaolin from paper sludge. Advanced Cement Based Materials, 7, Iss. 2, 49-56. DOI: $10.1016 / \mathrm{S} 1065-7355(97) 00016-3$
Salvador, S.: 1995, Pozzolanic properties of flash-calcined kaolinite: A comparative study with soak-calcined products. Cement and Concrete Research, 25, Iss. 1, 102-112. DOI: 10.1016/0008-8846(94)00118-I

San Cristóbal, A.G., Castelló, R., Martín Luengo, M.A. and Vizcayno, C.: 2010, Zeolites prepared from calcined and mechanically modified kaolins: A comparative study. Applied Clay Science, 49, Iss. 3, 239-246. DOI: $10.1016 /$ j.clay.2010.05.012

Shvarzman, A., Kovler, K., Grader, G.S. and Shter, G.E.: 2003, The effect of dehydroxylation/amorphization degree on pozzolanic activity of kaolinite. Cement and Concrete Research, 33, Iss.3, 405-416. DOI: $10.1016 / \mathrm{S} 0008-8846(02) 00975-4$

Slade, R.C.T., Davies, T.W., Atakül, H., Hooper, R.M. and Jones, D.J.: 1992, Flash calcines of kaolinite: Effect of process variables on physical characteristics. Journal of Materials Science, 27, Iss. 9, 2490-2500. DOI: $10.1007 / \mathrm{BF} 01105062$

Souza, P.S.L. and Molin, D.C.C.D.: 2005, Viability of using calcined clays, from industrial by-products, as pozzolans of high reactivity. Cement and Concrete Research, 35, Iss. 10, 1993-1998.

DOI: 10.1016/j.cemconres.2005.04.012

Tironi, A., Trezza, M.A., Scian, A.N. and Irassar, E.F.: 2012, Kaolinitic calcined clays: Factors affecting its performance as pozzolans. Construction and Building Materials, 28, Iss. 1, 276-281.

DOI: $10.1016 / j$.conbuildmat.2011.08.064

Velosa, A.L., Rocha, F. and Veiga, M.R.: 2009, Influence of chemical and mineralogical composition of metakaolin on mortar characteristic. Acta Geodyn. Geomaterialia, 6, No. 1, 121-126.

Vizcayno, C., Gutiérrez, R.M., Castello, R., Rodriguez, E. and Guerrero, C.E.: 2010, Pozzolan obtained by mechanochemical and thermal treatments of kaolin. Applied Clay Science, 49, Iss. 4, 405-413. DOI: $10.1016 /$ j.clay.2009.09.008 